University of South Florida

DIGITAL COMMONS

Digital Commons @ University of

@ UNIVERSITY OF SOUTH FLORIDA

South Florida

1990

\title{
Variability in Upwelling Fields in the Northwestern Indian Ocean 1. Model Experiments for the Past 18,000 Years
}

Mark E. Luther

Florida State University, mluther@usf.edu

Follow this and additional works at: https://digitalcommons.usf.edu/msc_facpub

Part of the Life Sciences Commons

\section{Scholar Commons Citation}

Luther, Mark E., "Variability in Upwelling Fields in the Northwestern Indian Ocean 1. Model Experiments for the Past 18,000 Years" (1990). Marine Science Faculty Publications. 498.

https://digitalcommons.usf.edu/msc_facpub/498

This Article is brought to you for free and open access by the College of Marine Science at Digital Commons @ University of South Florida. It has been accepted for inclusion in Marine Science Faculty Publications by an authorized administrator of Digital Commons @ University of South Florida. For more information, please contact digitalcommons@usf.edu. 
VARIABILITY IN UPWELLING FIELDS IN THE

NORTHWESTERN INDIAN OCEAN

1. MODEL EXPERIMENTS FOR THE PAST 18,000 YEARS

Mark E. Luther ${ }^{1}$ and James J. O'Brien

Mesoscale Air-Sea Interaction Group, Florida State

University, Tallahassee

Warren L. Prell

Department of Geological Sciences, Brown

University, Providence, Rhode Island respectively, of the jet axis. This drives much stronger upwelling to the northwest of the jet axis and downwelling to the southeast. In the $18 \mathrm{kyr}$ B.P. case, the Findlater Jet is very weak, and upwelling patterns are uniformly weak across the basin. The spatial distribution and temporal variation of the upwelling fauna in the sediment record is consistent with the model upwelling fields in all three cases. The ocean model thus provides the link between the climate model and the sedimentation data, verifying the hypothesis that variations in upvelling driven by variations in the strength of the monsoon jet are responsible for the observed variations in the sediment record.

\section{INTRODUCTION}

The dramatic reversals in the monsoon winds of the Indian Ocean drive corresponding reversals in the surface currents. Associated with these reversals are regions of strong upwelling that drive high rates of primary productivity. A wealth of geological evidence from lake levels, pollen profiles and deepsea cores provides paleoclimatic records of monsoon variability. In addition, numerous model studies have demonstrated variability in the monsoons over geologic time (see Hastenrath [1985] or Kutzbach [1987] for a review). Over the last glacial-interglacial period, the strength of the monsoon winds has varied greatly, due to changes the Earth's orbital parameters and in surface boundary conditions, such as in albedo over the Tibetian Plateau and in sea surface temperature (SST) over the Indian Ocean [Kutzbach and Guetter, 1986; Prell and Kutzbach, 1987].

The tests of planktonic organisms are deposited in the underlying oceanic sediments to preserve a record of changes in monsoonal upwelling. The response of modern plankton to upwelling has been determined by mapping their distribution in surface seafloor sediments and comparing their abundance and size gradients to various upwelling-associated gradients such as SST [Hutson and Prell, 1980; Prell and Curry, 1981; Prell, 1984a,b; Cullen and Prell, 1984]. For example, one 
assemblage of planktonic foraminifera, characterized by Globigerina bulloides, seems particularly well attuned to the upwelling environment. Maps of this assemblage reveal high abundance along the coast of Arabia and decreased abundance toward the central Arabian Sea, where the abundance of the normal tropical assemblage increases. This spatial pattern is coincident with that of low SST and high phosphate content during the summer months, and documents that plankton can be associated with the monsoonal upwelling pattern.

Studies of Late Quaternary sediments of the Owen Ridge and the continental margin of Arabia by Prell [1984a] and Prell and van Campo [1986] reveal that monsoonal upwelling was significantly stronger 9000 years before present ( 9 kyr B.P.) than in modern times (Figure 1). Prell et al. [1980] show that monsoonal upwelling was weaker during the last glacial maximum at 18 kyr B.P. Such observations are consistent with independent records of monsoon variability from data on the distribution of pollen in both terrestrial and deep sea sediments [van Campo et al., 1982; van Campo, 1983], from reconds of changing lake levels [Street-Perrott and Harrison, 1984] and from model simulations of past climates [Kutzbach, 1981; Kutzbach and Otto-Bliesner, 1982; Kutzbach and Guetter, 1986; Prell and Kutzbach, 1987].

Kutzbach and Guetter [1986] and Prell and Kutzbach [1987] use the National Center for Atmospheric Research (NCAR) Community Climate Model (CCM) to show that the changes in the Asian monsoon system between $18 \mathrm{kyr}$ B.P. and modern times are due partially to orbital-induced changes in the seasonal radiation cycle combined with the different thermal properties of land and ocean and the nonlinear relationship

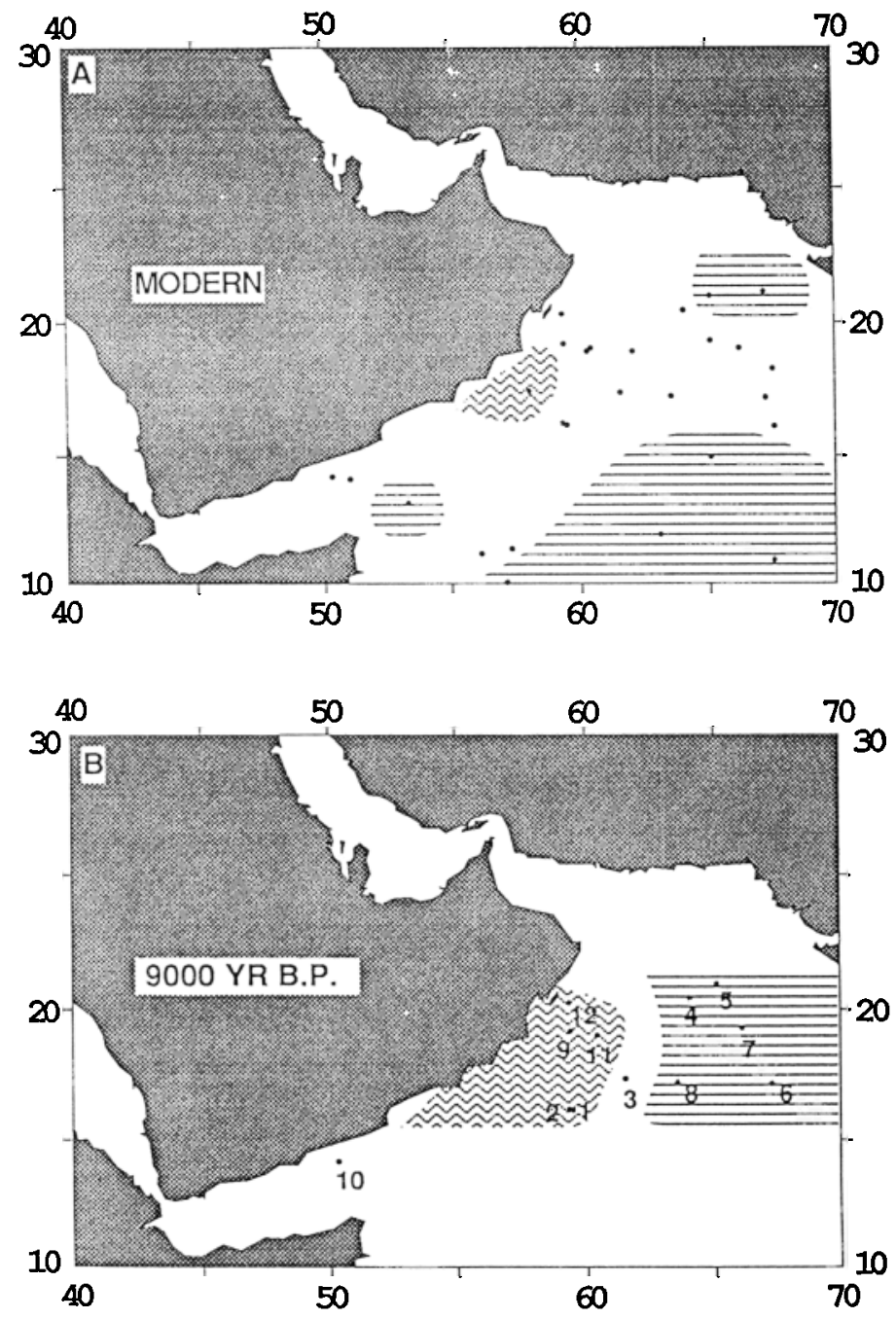

Fig. 1. Distribution of the upwelling and tropical assemblage for modern and 9 kyr B.P. from sediment cores. Stipled areas indicate factor loadings for the upwelling asscmblage of greater than 0.6. Hatched areas indicate factor loadings for the tropical assemblage of greater than 0.6. There is a large increase in the concentration of the upwelling assemblage in the sediments near the Arabian coast at 9 kyr B.P. as compared to modem conditions. The position of the boundary between upwelling fauna and tropical fauna shows little change. 
between temperature and saturation vapor pressure. During the last glacial maximum, about 18 kyr B.P., perihelion occurred in northern winter and the tilt of the Earth's axis was a minimum. The Tibetian Plateau had increased albedo throughout the year, due to increased ice and snow cover. The adjacent oceans had areas of SSTs that were both lower and higher than at present. The large land-sea temperature difference that drives the Asian southwest monsoon system was very weak; consequently, the southwesterly monsoon winds over the northwestem Indian Ocean were very weak. Conversely, by about 9 kyr B.P., perihelion occurred in July and the Earth's axial tilt was at a maximum, which enhanced summer warming and winter cooling in the northern hemisphere. Most of the glacial ice sheets had disappeared and SSTs approached present conditions. These factors combined to drive monsoon winds that were stronger than those of today. Prell and Kutzbach [1987] find good agreement between the modelled and observed paleoclimatic records for this period.

In this paper, variability in upwelling in the northwestern Indian Ocean is investigated using the numerical ocean model of Luther and O'Brien [1985] and the surface winds computed from the NCAR CCM by Kutzbach and Guetter [1986] for 0 , 9, and $18 \mathrm{kyr}$ B.P. simulations. Part 2 of this paper [Prell et al., this issue] describes the sediment data for modern and $9 \mathrm{kyr}$ B.P. periods in greater detail in the context of the model simulations.

The ocean model realistically simulates the response of the Indian Ocean to observed wind forcing. Previous model simulations using both modem climatological winds [Luther and $O^{\prime} B r i e n, 1985 ;$ Woodberry et al., 1989] and winds for specific years [Luther et al., 1985; Simmons et al., 1988] show good agreement with available observations. The model reproduces the reversal of the Somali Current during the transitions between monsoons as well as the intense eddies and upwelling regions along the coasts of Somalia and the Arabian Peninsula associated with the northern hemisphere summer monsoon. The formation and collapse of the observed two gyre system in the summer Somali Current agrees quite well with the description by Schott [1983] and by Swallow et al. [1983]. A southern gyre forms south of $2^{\circ} \mathrm{N}$ in May, in response to the onset of southwesterly winds, and a northern gyre, called the great whirl, forms at about $4^{\circ}-5^{\circ} \mathrm{N}$ in June, in response to the strengthening of the atmospheric Findlater Jet [Findlater, 1971] at those latitudes. Strong upwelling occurs along the coast of Somalia and Arabia and out at least $400 \mathrm{~km}$ from the coast, driven by both the alongshore component of the winds and by the strong positive wind stress curl beneath the cyclonic side of the Findlater Jet, leading to a superposition of coastal upwelling and open ocean upwelling [Smith and Bottero, 1977]. In mid- to late August, the southern gyre migrates northward to merge with the great whirl. As the southwest monsoon winds relax, the summer Somali Current decays and is replaced by the southward winter Somali Current with the onset of the northeast monsoon in December (for a review of the physical oceanography of this region, see Knox [1987]).

Simmons et al. [1988] perform a model validation study for the fall of 1985 and find good agreement between model upper layer thickness and observed thermocline depth and SST for the dynamically active regions of the northwestem Arabian Sea. Luther and $O^{\prime} B r i e n$ [1989] demonstrate that variability in the model is a direct consequence of variability in the wind ficld and is not due to inherent variability contained in the physics of the model. In the present study, we therefore treat the model fields as adequately simulating the ocean's response to the imposed winds and treat the variability in the model fields as an expression of that in the ocean.

\section{THE MODEL}

Information on ocean upwelling is derived from the model of Luther and O'Brien [1985]. The model is a nonlinear reduced gravity model that covers the Indian Ocean from $40^{\circ} \mathrm{E}$ to $74^{\circ} \mathrm{E}$ and from $10^{\circ} \mathrm{S}$ to $26^{\circ} \mathrm{N}$ at a resolution of $1 / 8$ degree longitude and 1/4 degree latitude (Figure 2). This high horizontal resolution is necessary to model the highly nonlinear flows found in the intense eddies in this region. The model geometry follows the $200 \mathrm{~m}$ isobath, so that glacial/interglacial changes in sea level do not affect the area of the model domain. The large shallow banks around Socotra, the Seychelles, the Maldives, the Laccadives and the Chagos Archipelago appear as land areas in all cases. These banks at present sea level are typically less than $30 \mathrm{~m}$ deep and are dotted with reefs and small islands, so that they effectively present solid boundaries to flow. The model simulates the response of the upper layer of the ocean to an applied surface wind stress. In the reduced gravity approximation, the density stratification of the ocean is represented by two hydrostatic, Bousinesq fluid layers in the vertical of slightly different densities, with the further requirement that the depth-integrated transport in the lower layer vanishes. The model dependent variables are the upper layer thickness $(H)$, the zonal upper layer transport (U), and the meridional upper layer transport (V). Boundary conditions are no-slip along land boundaries. Open boundary conditions are applied along the southern boundary and along a portion of the eastem boundary.

The model is driven by winds from the NCAR CCM computed by Kutzbach and Guetter [1986] for present conditions ( $0 \mathrm{kyr}$ B.P.), for $9 \mathrm{kyr}$ B.P. and for $18 \mathrm{kyr}$ B.P. Orbital parameters (eccentricity, axial tilt, date of perihelion) and lower boundary conditions (sea surface temperature, sea-ice limit, snow cover, effective soil moisture) are prescribed to their estimated values for each time period. Atmospheric $\mathrm{CO}_{2}$ is held constant at $330 \mathrm{ppmv}$ in all cases. In each of these three cases, Kutzbach and Guetter [1986] provide surface winds on a $4.4^{\circ}$ latitude by $7.5^{\circ}$ longitude grid from perpetual January and perpetual July simulations. The wind fields for these simulations represent the means of three 90 -day averages from 450-day model runs. These wind data are interpolated in space to the model grid using the natural bicubic spline interpolant and in time using a single annual Fourier harmonic. Wind stress is computed using the standard bulk aerodynamic formula with a drag coefficient of $1.5 \times 10^{-3}$ and an air density of $1.2 \mathrm{~kg} \mathrm{~m}^{-3}$. This drag coefficient is chosen so that the magnitude of the maximum stresses in the $0 \mathrm{kyr}$ B.P. control case are within the range of modem observed values used in previous studies [Luther et al., 1985; Simmons et al., 1988]. Wind stress fields for July of each case are shown in Plate 1. Values of model parameters used are the reduced gravity coefficient, $g^{\prime}=0.03 \mathrm{~m} \mathrm{~s}^{-2}$, and a kinetic eddy viscocity, $A_{V}=750 \mathrm{~m}^{2} \mathrm{~s}^{-1}$. For each case, the model is initialized to a 


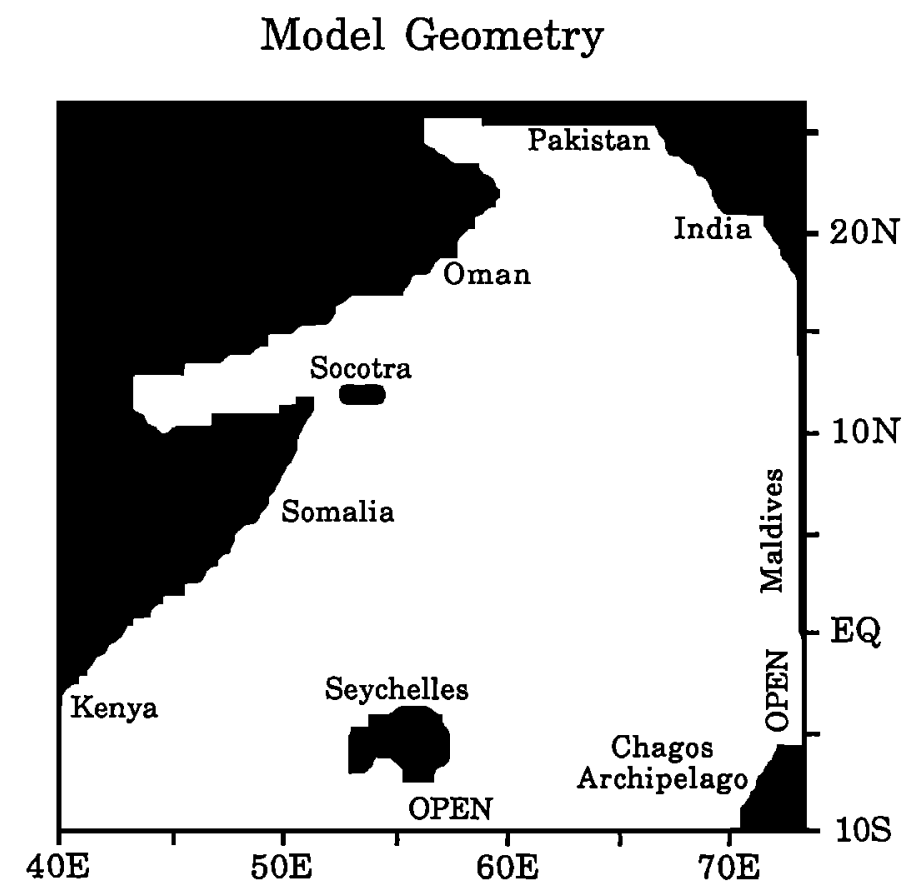

Fig. 2. Model geometry. The model geometry simulates the northwestern Indian Ocean form $40^{\circ} \mathrm{E}$ to $74^{\circ} \mathrm{E}$ and from $10^{\circ} \mathrm{S}$ to $26^{\circ} \mathrm{N}$. The southem boundary and a portion of the eastem boundary are open. The shallow banks around Socotra, the Seychelles, the Maldives, the Laccadives, and the Chagos Archipelago are parameterized as land areas, since they are typically less than $30 \mathrm{~m}$ deep.

state of rest, with $\mathrm{U}=\mathrm{V}=0$ and $\mathrm{H}=200 \mathrm{~m}$. The model is integrated forward in time for 3 years, with the annual wind cycle repeating each year. By the third year, the model produces a steady, repeating seasonal cycle. Results from the third year of each case are presented.

The initial value of $\mathrm{H}$ together with the value of $\mathrm{g}^{\prime}$ determine the mean stratification. While it is likely that the mean stratification of the oceans has changed over the past 18,000 years, it would be difficult to estimate reasonable stratification parameters for past climates. The same values of these parameters are used in each case in order to focus on the variability in upwelling due solely to changes in wind forcing.

We treat the model upper layer thickness $(\mathrm{H})$ fields as a surrogate variable for thermocline (or pycnocline) depth. A thinning of the upper layer implies upwelling and cooler SST, while a thickening upper layer implies downwelling and warmer SST. Variations in $\mathrm{H}$ are thus indicative of variations in heat content of the upper layer of the ocean and are thus expected to be positively correlated with SST variations. Additionally, a thinner upper layer enhances the effect of winddriven entrainment in lowering SST and increasing primary productivity by bringing cooler, nutrient-rich water nearer the surface where it can be more easily mixed upward, while a thicker upper layer reduces the efficiency of entrainment $2.1 d$ allows local heating to more effectively increase SST. The model does not explicitly include thermodynamic effects, and in some instances, thermodynamic effects will dominate the SST response; however, in the dynamically active regions of the Arabian Sea, variability in model upper layer thickness is highly correlated with SST variability, especially on longer time an space scales [Simmons et al., 1988].

As an indicator of upwelling strength, we compute the integrated, rectified upward interface displacement over the primary upwelling season of mid-April to mid-August. This time frame includes the onset and mature stages of the southwest monsoon and is the period of most active upwelling along the Arabian peninsula. Waters above the thermocline are typically nutrient depleted, while the waters below the thermocline are relatively nutrient-rich. We integrate only upward motions of the model interface, ignoring downward motions, since upward motions of the interface bring nutrientrich waters closer to the surface, where they can be mixed into the euphotic zone and sustain primary productivity, while downward motions of the interface do not remove these nutrients. This is admittedly a crude index of upwelling strength. This index has the negative properties that it rectifies small-amplitude oscillations so that they may appear as large upwelling signals and that it does not account for the initial depth of the interface (for example, an upward displacement from an initial depth of $80 \mathrm{~m}$ would be more effective in bringing nutrients toward the euphotic zone than the same displacement from an initial depth of $200 \mathrm{~m}$ ). It does capture the upwelling driven by the mechanisms of upward Ekman pumping and coastal Ekman divergence, which are shown to be the dominant mechanisms off the Arabian Peninsula [Smith and Bottero, 1977]. It is sufficient therefore 
for the purpose of investigating long-term climate variability in upwelling patterns in this region.

\section{WIND FORCING}

The wind fields used to drive the model are shown in Plate 1 for mid-July for each of the three cases. We focus on the July (the peak of the southwest monsoon) winds only, since it is these winds that are responsible for the primary upwelling season. An important forcing mechanism for the ocean circulation is the wind stress curl. Beneath the Findlater Jet, it is the spatial gradient of the curl that is important for the ocean's response [Luther et al., 1985]. The strong horizontal shear of the surface winds in the jet lead to a differential Ekman pumping, with upward Ekman pumping in the cyclonic shear region to the northwest of the Jet axis and downward pumping in the anticyclonic shear region to the southeast. The upward pumping lifts the pycnocline (or the model interface), while the downward pumping depresses it. The line of zero curl, which delineates the axis of the Findlater Jet, thus represents a line of pivot for the pycnocline. As the pycnocline slopes, an oceanic jet forms along the slope through geostrophic adjustment. Since the time scale of the onset and decay of the monsoon winds is short compared to the Rossby wave adjustment time scale, the oceanic response remains localized beneath the Findlater Jet until after the decay of the winds, when westward propagation and instability processes become important.

The southwest monsoon winds over the northem hemisphere and their associated curl are stronger in the $9 \mathrm{kyr}$ B.P. case and weaker in the $18 \mathrm{kyr}$ B.P. case than in the control. In both the 9 and $18 \mathrm{kyr}$ B.P. cases, the axis of the Findlater Jet is located farther to the north than in the control. The regions of cyclonic and anticyclonic curl on either side of the Jet axis are as much as 35-50\% stronger in the $9 \mathrm{kyr}$ B.P. case than in the control and approximately $60 \%$ weaker in the $18 \mathrm{kyr}$ B.P. case. Equatorial winds have a weak westerly (i.e. from the west) zonal component in the $0 \mathrm{kyr}$ B.P. case but an easterly zonal component in both 9 and $18 \mathrm{kyr}$ B.P. cases. The southern hemisphere winds and their curl are strongest in the $18 \mathrm{kyr}$ B.P. case and weaker in the control case, with the 9 kyr B.P. case being intermediate to the two (for a complete discussion of the wind fields, see Kutzbach and Guetter [1986] and Prell and Kutzbach [1987]].

The time resolution of the CCM winds is exceedingly coarse, having only perpetual July and perpetual January simulations. For the model winds, these are fitted with a single Fourier harmonic (a sine function with an annual period) to simulate the seasonal cycle of the monsoon winds. There is some evidence to support the importance of the abrupt onset of the monsoon winds in the development of the Somali Current [Schott, 1983; Swallow et al., 1983], which requires higher harmonics in the representation of the winds; however, for the purposes of this study, the use of the single annual harmonic appears to be sufficient to model the overall features of the ocean circulation.

The spatial structure of the winds used here is much smoother than those derived from modem observations that are used in previous studies [Luther and $O^{\prime} B$ rien, 1985; Luther et al., 1985; Simmons et al., 1988; Woodberry et al., 1989].
This is due to the coarse resolution of the original CCM winds from which they are interpolated. The observed strength and position of the Findlater Jet are reasonably well represented in the control case, given the coarse resolution of the CCM winds; however, there are notable differences. The axis of the Findlater Jet takes a more zonal direction in the 0 and in the 9 kyr B.P. cases than in the July winds from modern climatologies and from some individual years ( see, for instance, Luther et al. [1985, Figures 16 and 17]); however, there is large interannual variability in the position and strength of the jet in the modem observations [Cadet and Diehl, 1984], and there are years in which the jet axis follows a path more like the $0 \mathrm{kyr}$ B.P. case. These observed wind fields are in a sense individual realizations, or ensembles of realizations, of the true climate. In the terminology of chaos theory, these wind fields are each individual orbits on an attractor, with that attractor being the true climate. It is assumed that the climate model is simulating this attractor, since it includes the relevant physical mechanisms controlling climate (E. Lorentz, personal communication, 1989). Although individual orbits or realizations will not match exactly any particular observed state of the atmosphere, the modeled atmosphere should approach the true climate in a statistical sense. The winds from the climate model are therefore sufficient to model the ocean's response to long-term, climate scale variability in atmospheric forcing.

\section{UPPER LAYER CIRCULATION}

In each case, a steady, repeating seasonal cycle is established in the model fields by the third year of integration, with the strongest upwelling occurring in the northwestern basin during the months between the transition from northeast to southwest monsoon in mid-April and the beginning of the decay phase of the southwest monsoon in mid-August. The model fields for mid-August (the end of the upwelling season) for each of the three cases are shown in Plate 2. In the $0 \mathrm{kyr}$ B.P. control case, the summer Somali Current develops much as in previous simulations using modern winds. At $0 \mathrm{kyr}$ B.P., a two gyre system forms in late May, with a collapse in early August. Smaller eddies are left in the wake of northwardmoving southern gyre after the collapse and are seen in Plate 2a. Little recirculation occurs at the equator after the southem gyre moves northward. A single large eddy is located to the north of Socotra, with southward flow through the channel to the west of Socotra. This is due to the position of the Findlater Jet axis, which remains to the south of Socotra in this case, as is often found in modern observations. The position of the line of zero wind stress curl, which defines the jet axis, is a strong constraint on the position of the great whirl, and of the southwest monsoon current (SMC) which flows out of the great whirl toward the northeast. The Socotra eddy forms in the SMC to the east of Socotra in late August and remains there until the onset of the northeast monsoon. The equatorial jets that form during the monsoon transitions are weak, and little equatorial wave activity occurs throughout the year. The southwestward winter Somali Current is established by early December. During the winter monsoon, the northward flowing East African Coastal Current (EACC) meets the winter Somali Current at $5^{\circ} \mathrm{S}$, where they turn offshore and meander into the interior. 

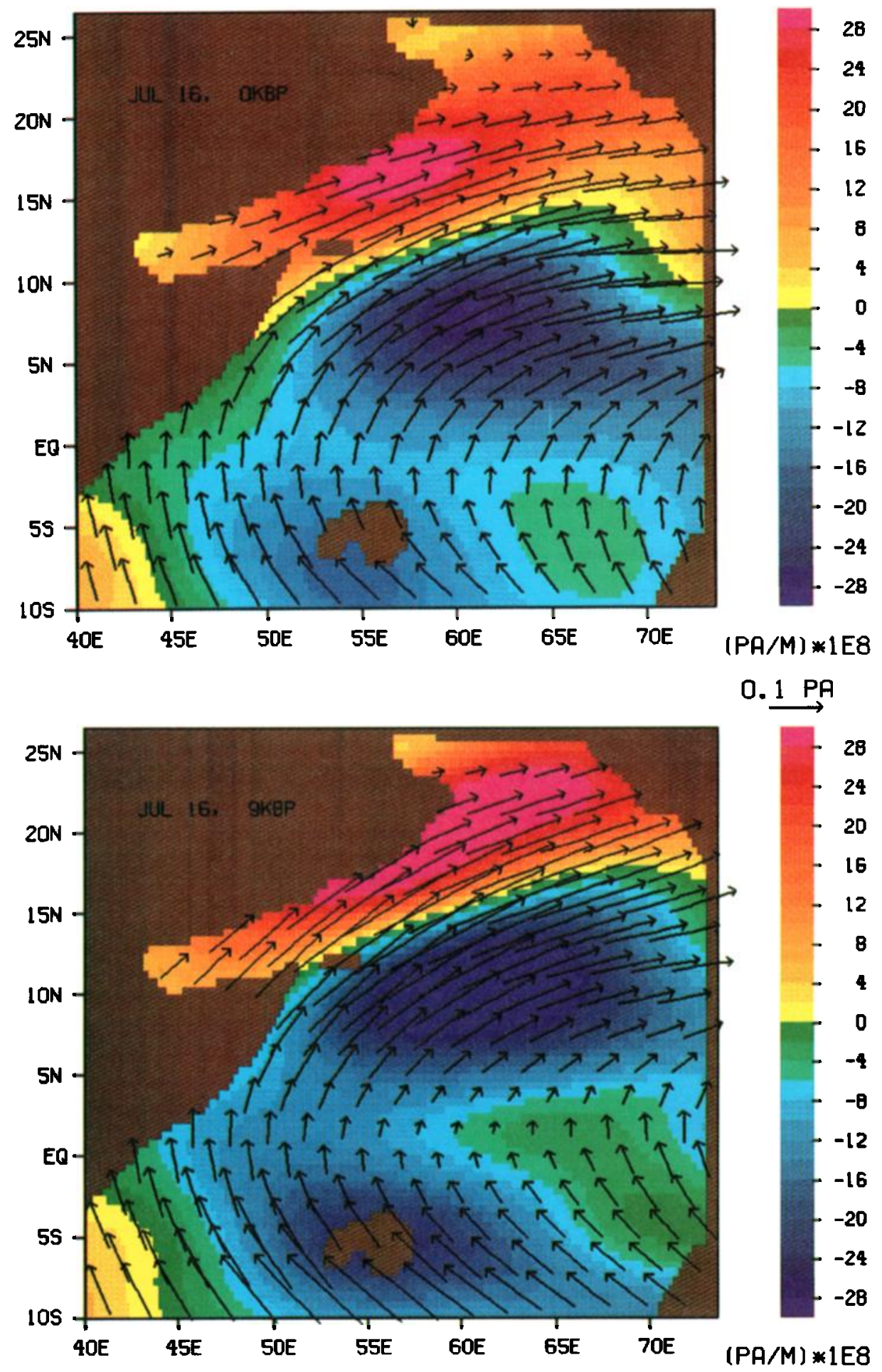

Plate 1. July winds from the NCAR Community Climats Model for (a) the control case (0 kyr B.P.); (b) 9 kyr B.P.; (c) $18 \mathrm{kyr}$ B.P. Arrows indicate wind stress and color indicates wind stress curl, with yellow to magenta indicating positive values and green to blue indicating negative values. Brown indicates land areas. The core of the Findlater Jet is indicated by the zero line of the curl. Both the Findlater Jet and its associated curl field are much stronger in the 9 kyr B.P. case than in the 0 kyr B.P. case and much weaker in the $18 \mathrm{kyr}$ B.P. case. 
$1 \mathbf{c}$
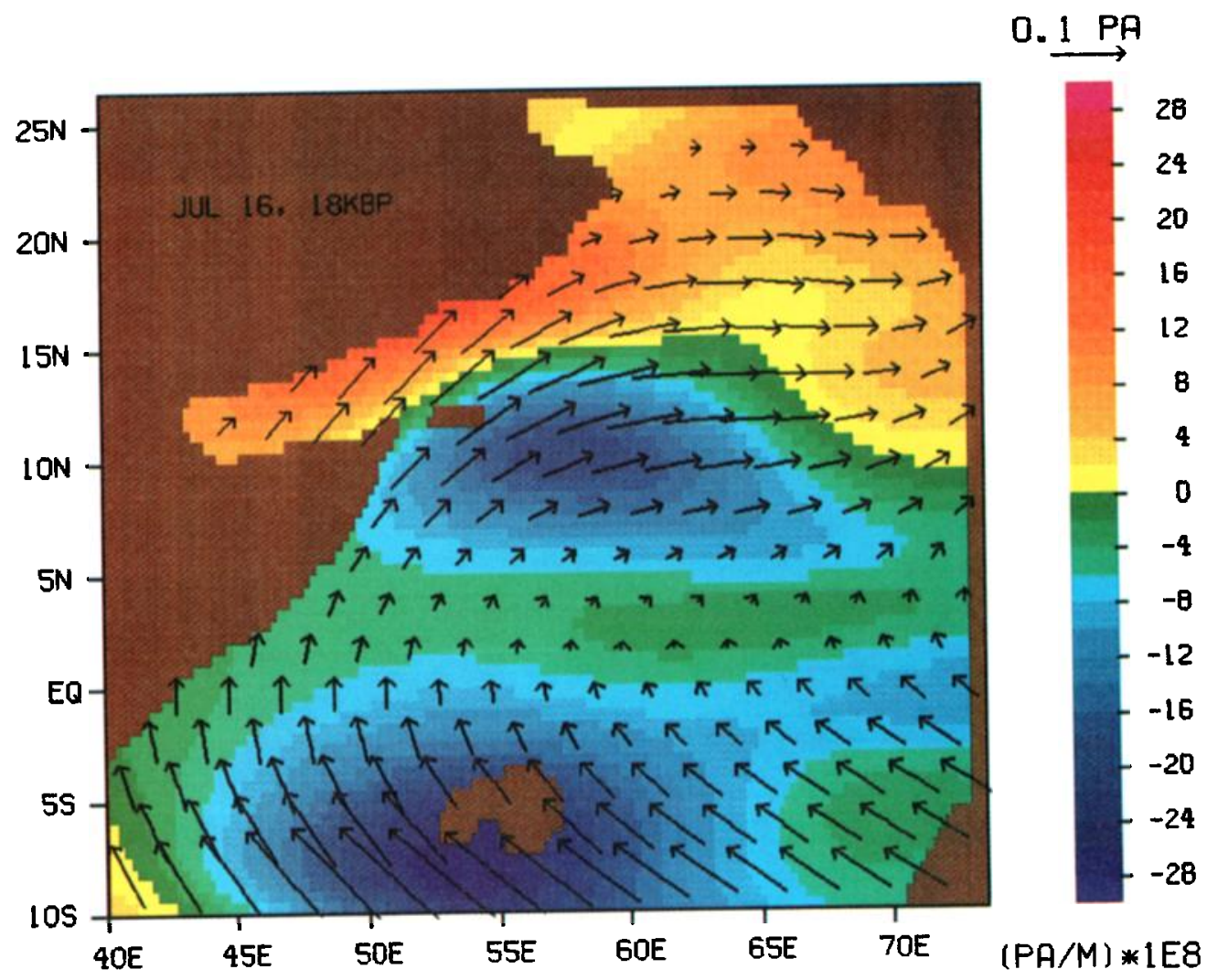

Plate 1(continued)

2 a

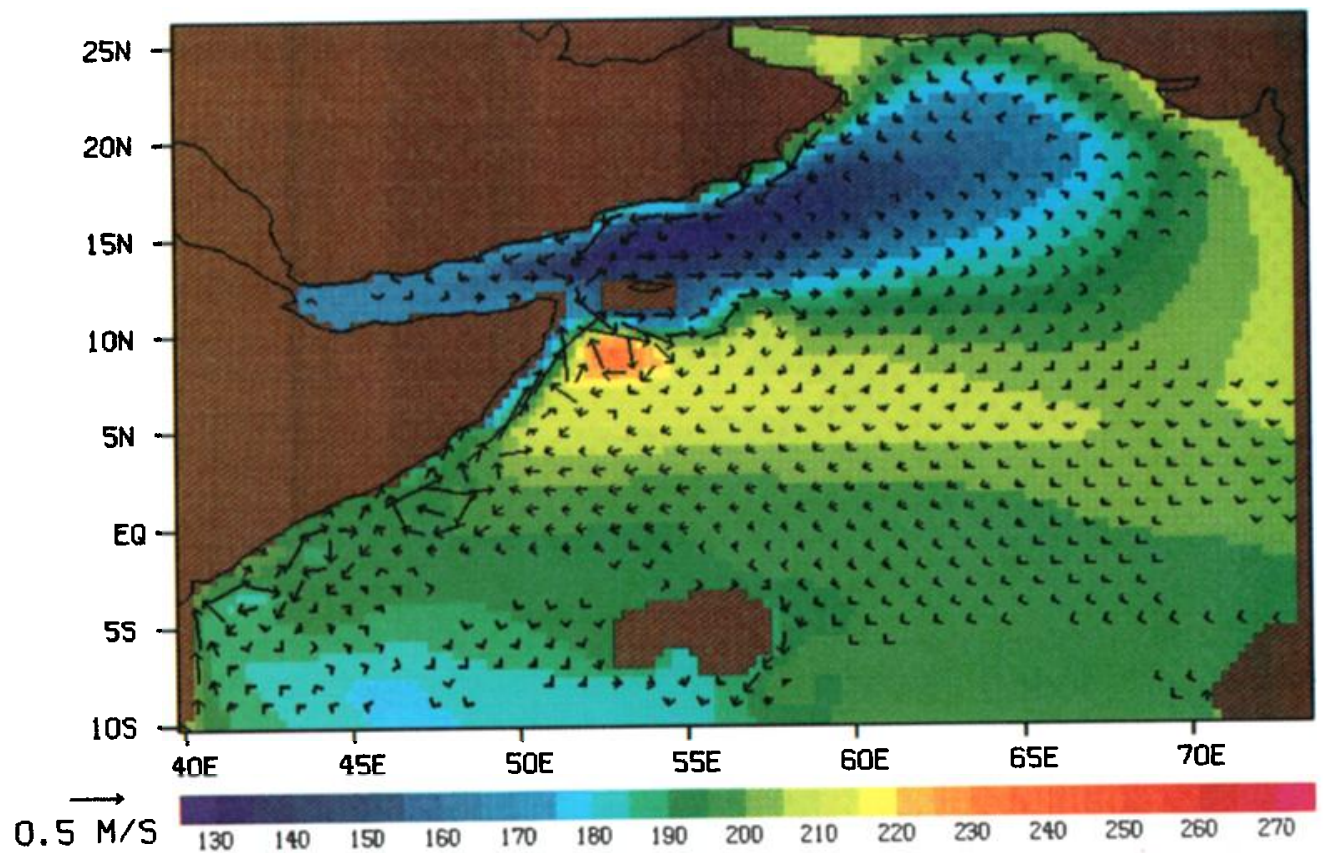

Plate 2. Model velocity and upper layer thickness fields for August 16 for (a) the control case (0 kyr B.P.); 
2b

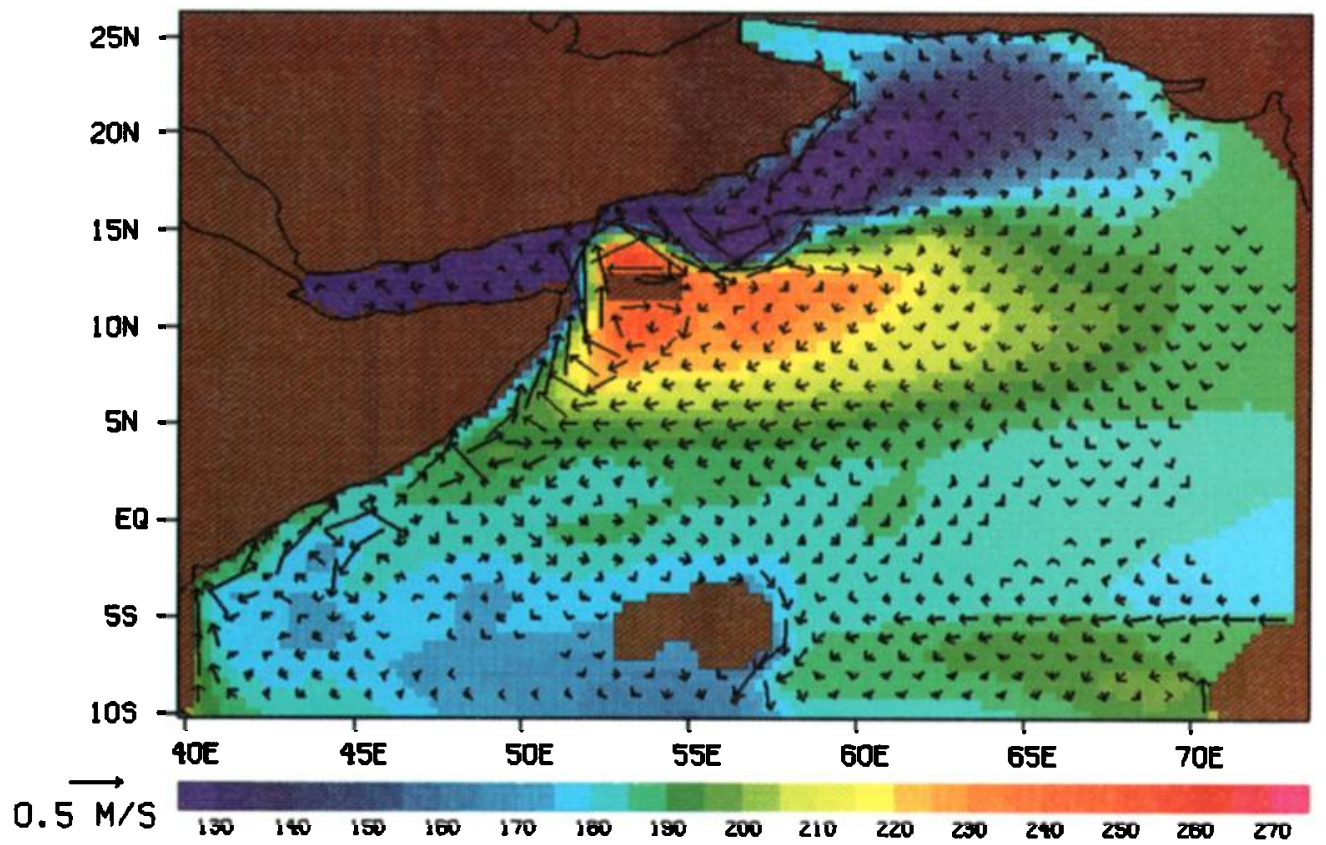

2c

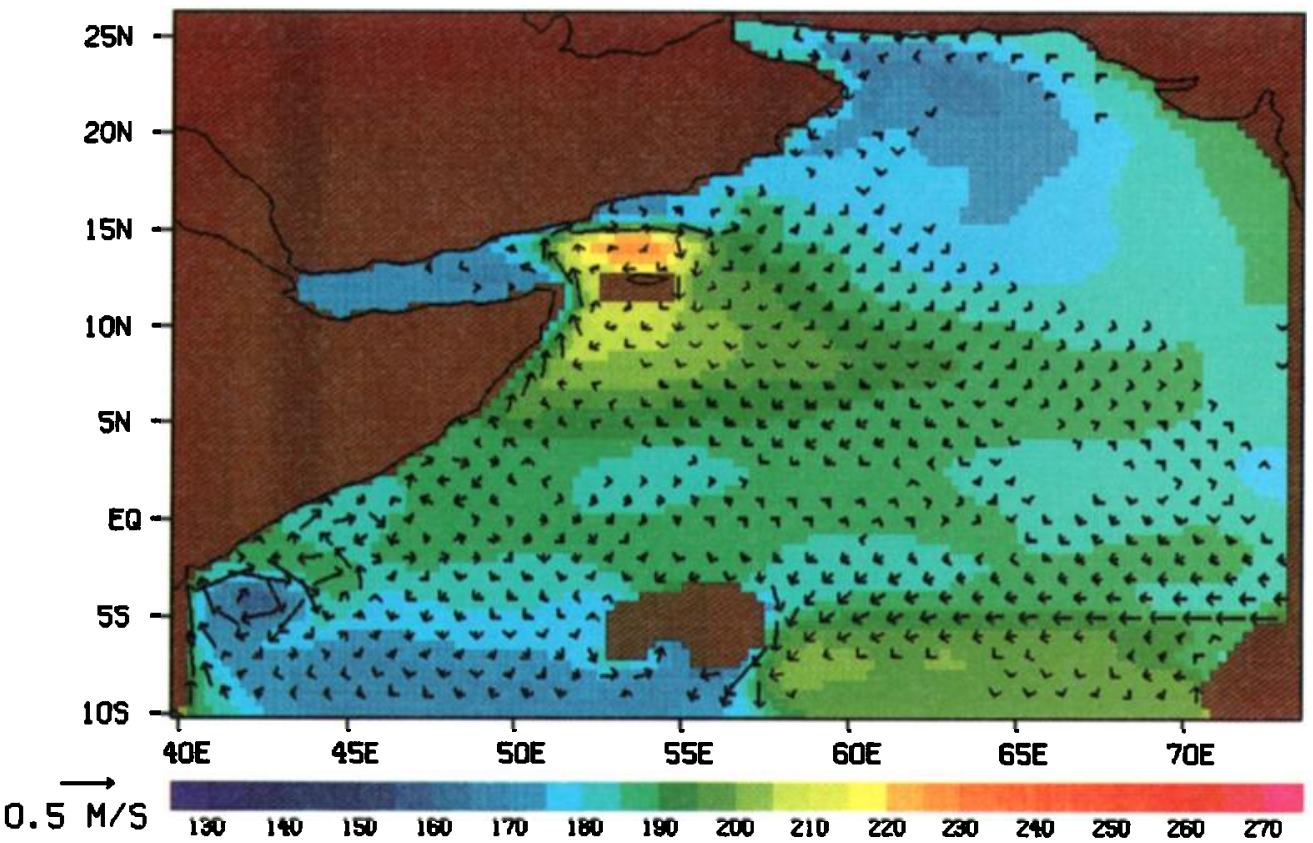

(b) $9 \mathrm{kyr} \mathrm{B.P.;} \mathrm{(c)} 18 \mathrm{kyr} \mathrm{B.P.} \mathrm{Arrows} \mathrm{indicate} \mathrm{velocity}\left(\mathrm{m} \mathrm{s}^{-1}\right)$ and color indicates upper layer thickness (m), with scales given at the bottom of the figure. Velocities greater than $1.0 \mathrm{~m} \mathrm{~s}^{-1}$ are truncated, while velocities less than $0.05 \mathrm{~m} \mathrm{~s}^{-1}$ are suppressed. The Somali Current and the Southwest Monsoon Current are much stronger in the $9 \mathrm{kyr}$ B.P. case than in the $0 \mathrm{kyr}$ B.P. case and much weaker in the $18 \mathrm{kyr}$ B.P. case. 
In the 9 kyr B.P. case, both winter and summer Somali Currents are much stronger than in the control case. A two gyre system is evident by late May. There is no evidence of collapse of the two gyre system; however, smaller eddies form between the great whirl and the southem gyre and are absorbed by the great whirl. This case resembles the blocking case described by Luther and Obrien [1989], wherein stronger than normal southern hemisphere winds drive a strong recirculation in the EACC that becomes trapped at the equator as seen in Plate 2b. A strong warm eddy lies to the north of Socotra, with northward flow through the channel forming by mid-July. In this case, the axis of the Findlater Jet is slightly to the north of Socotra, which allows the flow from the great whirl to surround the island. The SMC and the Socotra Eddy are much stronger, owing to the stronger Findlater Jet with its increased curl gradient. Two large cold eddies are located off the coast of Arabia that formed under the influence of the strongly positive wind stress curl to the northwest of the jet axis. During the fall and winter months, the Socotra Eddy moves between these two cold eddies toward the Arabian Coast. The winter Somali Current is established in mid- to late November. The EACC is stronger and meets the winter Somali Current at $2-3^{\circ} \mathrm{S}$. The circulation across the southern hemisphere basin is stronger throughout the year due to the stronger wind stress and wind stress curl. Very strong equatorial jets with very large amplitude equatorial waves are present during the winter monsoon and the spring transition.
The equatorial jets are driven by the zonal component of the equatorial winds [Wyrtki, 1973; O'Brien and Hurlburt, 1974], while the equatorial waves are generated by the eddy activity at the western boundary [Kindle and Thompson, 1989; Woodberry et al., 1989], which is in turn driven by the increased southern hemisphere winds.

The $18 \mathrm{kyr}$ B.P. case is marked by a very weak summer Somali Current driven by the weak southwest monsoon winds. There is no SMC or Socotra Eddy and no cold eddies along the Arabian Peninsula, only a weak clockwise warm eddy the surrounds the island of Socotra (Plate 2c). The winter Somali Current, on the other hand, is much stronger than in the control case, and is driven by the increased northwest monsoon winds. There are strong equatorial oscillations during the winter monsoon, with strong southern hemisphere circulation throughout the year. The EACC flows offshore at $2^{\circ} \mathrm{S}$ throughout the year, with a strong recirculation in summer.

\section{UPWELLING PATTERNS}

Upwelling patterns for each case are inferred from upward movements of the model interface as described in section 2. For comparison of upwelling strength among the three cases, we integrate upward motions of the interface at each model grid point over the upwelling season of April 16 to August 16. These integrated fields are shown in Plate 3 for the northern

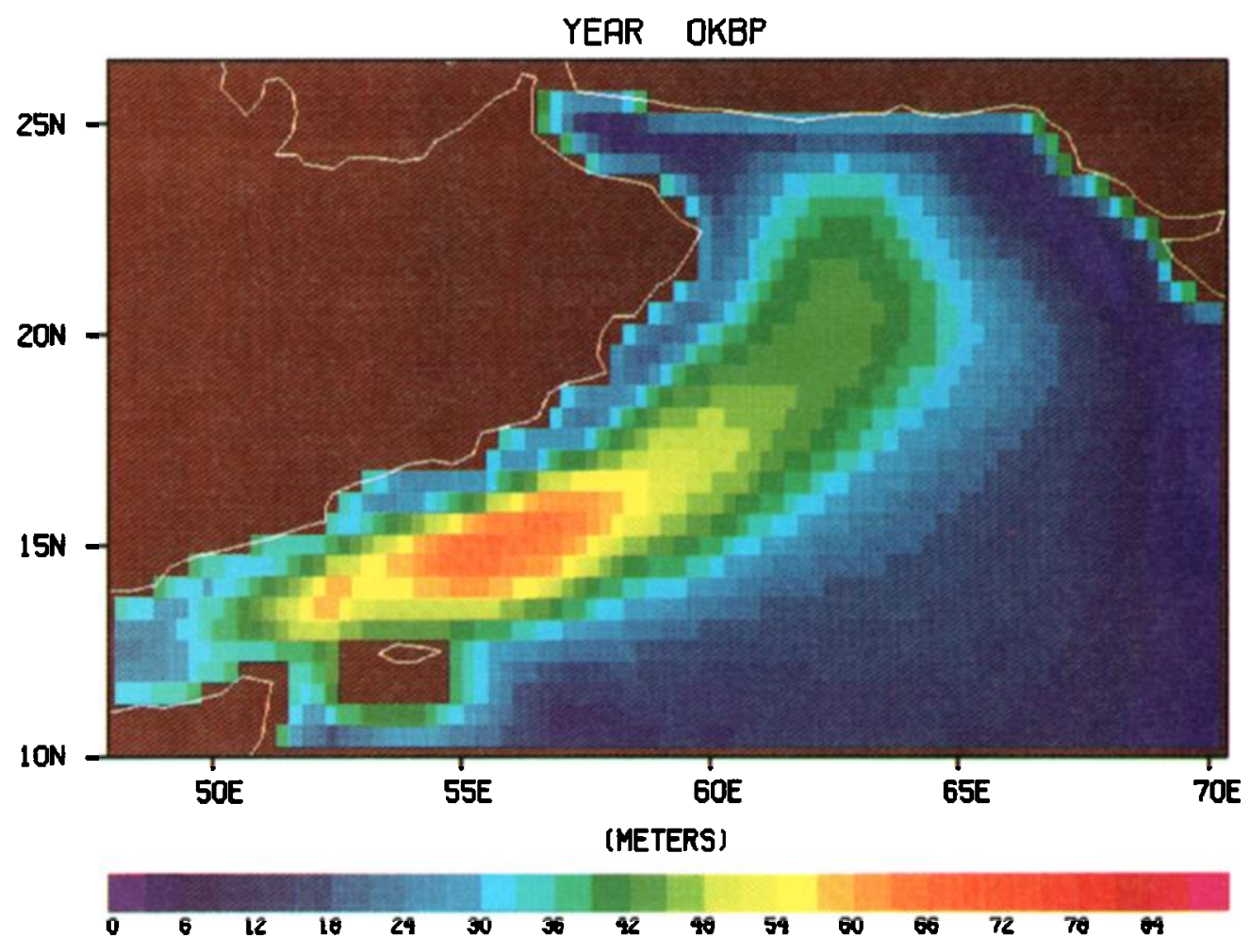

Plate 3. Model upward interface displacement (m) summed over the upwelling season of April 16 to August 16 for (a) the control case (0 kyr B.P.); (b) 9 kyr B.P.; (c) $18 \mathrm{kyr}$ B.P. Color scale is given below each figure. 
$3 b$
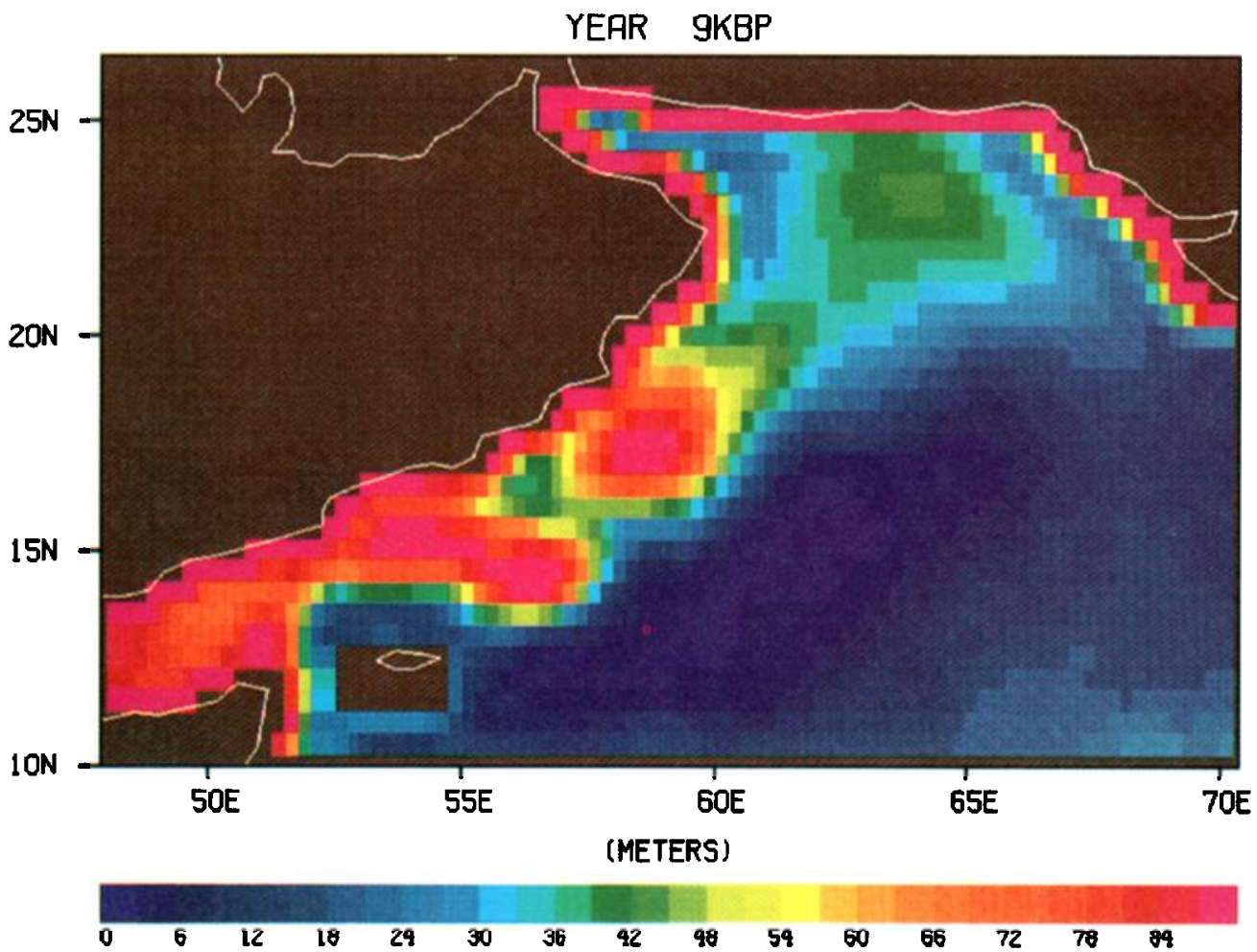

$3 c$

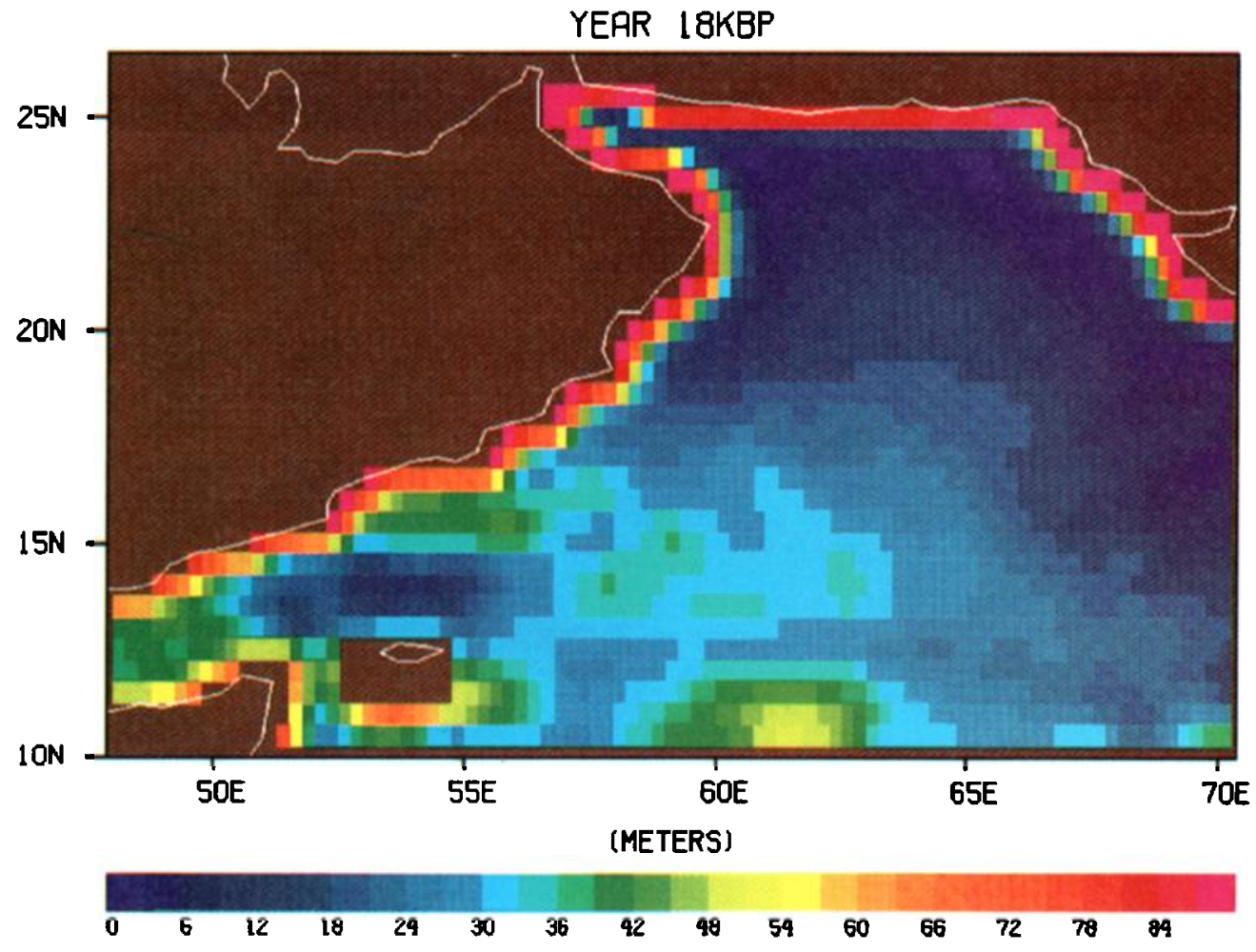

Plate 3 (continued) 
hemisphere portion of the model basin. The upwelling off the coast of Arabia is much stronger in the $9 \mathrm{kyr}$ B.P. case than in the control case and much weaker in the $18 \mathrm{kyr}$ B.P. case. The majority of the upwelling in all three cases is open ocean (or wind stress curl driven) upwelling, as opposed to coastal upwelling.

The focus of this study is on the area of high upwelling in the northwestern Arabian Sea. In the control case, the broad band of upwelling extends along the Arabian Peninsula from $51^{\circ} \mathrm{E}$ to $65^{\circ} \mathrm{E}$ and out approximately $450-500 \mathrm{~km}$ from the coast, with upward displacements of 40-70 m. Values of upward displacement in the central Arabian Sea are on the order of $12 \mathrm{~m}$. In the $9 \mathrm{kyr}$ B.P. case, the pattem is similar, but the effects of the stronger wind stress curl and of the northwestward displacement of the Jet axis are apparent. The band of upwelling extends $350-400 \mathrm{~km}$ offshore, with a much sharper gradient at its offshore edge. This sharp gradient coincides with the line of zero wind stress curl in Plate $1 \mathrm{~b}$. The line of zero wind stress curl should mark the boundary between upwelling fauna and more tropical mid-ocean fauna. Maximum upward displacements are greater than $80 \mathrm{~m}$ in the upwelling band, while values in the central Arabian Sea are less than $3 \mathrm{~m}$. In contrast, at $18 \mathrm{kyr}$ B.P. values of upward displacement are uniformly less than $15 \mathrm{~m}$ over most of the Arabian Sea, except for a narrow (less than one grid point) band of coastal upwelling along the boundary.

The patchiness of the upward displacement field in the $9 \mathrm{kyr}$ B.P. case is due to the increased nonlinearity of the flow field resulting from the increased amplitude of the forcing. It is not expected that this patchiness would be preserved in the sediment record, since year to year variability in the wind forcing and the subsequent location of the eddies, as is seen in modern times [Simmons et al., 1988; Luther and O'Brien, 1989], would tend to smooth the long-term upwelling signature.

Sediment cores from the northwestem Indian Ocean indicate that upwelling rates were much higher $9 \mathrm{kyr}$ B.P. than at present and were much lower $18 \mathrm{kyr}$ B.P. The spatial distribution and temporal variation of the upwelling fauna in the sediment record, such as Globigerina bulloides, are consistent with that of the model upwelling fields in all three cases. Upwelling fauna are concentrated in a band from the coast of Oman out to $60^{\circ} \mathrm{E}$ between $15^{\circ}$ and $20^{\circ} \mathrm{N}$ and show a maximum in abundance at $9 \mathrm{kyr}$ (Figure 1). Farther offshore, more tropical fauna are found, indicating warmer waters and a deeper thermocline, again with an increased abundance at 9 kyr B.P. At $18 \mathrm{kyr}$, the abundance of upwelling species is much reduced throughout the region. The boundary between upwelling fauna and tropical fauna is similar to that inferred from the model upwelling fields. The $100 \mathrm{~km}$ northwestward shift of the line of zero wind stress curl seen in the wind fields from the control to the $9 \mathrm{kyr}$ B.P. case, and reflected in the model upwelling fields, is not reflected in the sediment data; however, this distance is much less than the original resolution of the NCAR CCM winds and approaches the resolution of the sediment data and of the ocean model. It is not clear what significance should be attributed to this discrepancy.

A band of high upward displacement values is found along the equatorial wave guide in the 9 and $18 \mathrm{kyr}$ B.P. cases. This is due to the combined effects of Ekman divergence at the equator and the rectification of equatorial waves but does not result in low values of upper layer thickness (Plate $2 \mathrm{~b}$ and $2 \mathrm{c}$ ). The easterly zonal component of the equatorial winds in these two cases drives an Ekman divergence, and hence upwelling, along the equator, while the westerly zonal winds in the control case drive an Ekman convergence and equatorial downwelling. The narrow band of upwelling around the boundaries in the 9 and $18 \mathrm{kyr}$ B.P. cases is due to the rectification of coastal Kelvin waves. The difference between these two cases and the control case is in the excitation of equatorial waves. The enhanced southem hemisphere circulation as well as the increased amplitude of the wind forcing in the equatorial region at 9 and at $18 \mathrm{kyr}$ B.P. leads to an increase in the amplitude and number of equatorial waves (primarily Kelvin, Rossby and mixed Rossby-gravity waves) as seen in Moore and McCreary [1990], Kindle and Thompson [1989], and Woodberry et al. [1989]. The eastward propagating Kelvin waves and the short Rossby waves and mixed Rossby-gravity waves that have eastward group propagation, generate coastal Kelvin waves when they reach the eastern boundary of the model. These waves propagate counterclockwise around the northern portion of the basin, leading to the increased values of upward displacement in the narrow coastal band. The equatorial Kelvin waves generated by the easterly component of the winds in the 9 and $18 \mathrm{kyr}$ B.P. cases are upwelling disturbances and generate upwelling coastal Kelvin waves at the eastern boundary, while those generated by the westerly winds in the control are downwelling disturbances.

The sediment data do not indicate an increase in equatorial upwelling at 9 and at $18 \mathrm{kyr}$ B.P. The indication of stronger equatorial upwelling seen in the band of high upward displacement values near the equator in these two cases is suspect for the following reasons. The use of only a single annual harmonic to approximate the seasonal variability in the wind fields is not valid at the equator, as there is a strong semiannual oscillation in the equatorial winds over the Indian Ocean in modern observations [see Knox, 1987]. These semiannual oscillations generate both upwelling and downwelling equatorial waves, as well as the equatorial jets that are observed during the monsoon transitions.

Additionally, the observed modern winds display large interannual variability in the strength and direction of the equatorial winds. This interannual variability may be as large as the climate variability in the CCM winds. As discussed in section 3, the CCM winds used to drive the ocean model are only one particular realization (actually an ensemble of realizations) of the modelled climate, which is assumed to mimic the true climate. The addition of interannual variability may increase or decrease the upwelling in the equatorial region in the cases considered. This caveat does not apply to the region off the Arabian peninsula, since the interannual variability in modern winds observed there is much lower than the climate scale variability seen in the CCM winds. The equator is also a strong wave guide where high-frequency, lowamplitude oscillations are ubiquitous. As mentioned above, the rectification of high frequency oscillations in the chosen upwelling index may lead to over estimation of the magnitude of upwelling along the equator. 


\section{CONCLUSIONS}

Using a numerical ocean model driven by paleoclimatic model wind fields, we have shown that changes in monsoon winds over the past 18,000 years drive corresponding changes in upwelling rates in the northwestern Arabian Sea. The stronger southwest monsoon winds of 9 kyr B.P. drive higher upwelling rates and a more energetic oceanic circulation, primarily through the increased wind stress curl. The weak southwest monsoon winds of $18 \mathrm{kyr}$ B.P. drive correspondingly weak upwelling and circulation patterns in the northwest Arabian Sea. The temporal variations and spatial patterns of the model upwelling fields are consistent with sediment data from this region. The ocean model thus provides a link between the paleoclimate model and the sedimentation data, verifying the hypothesis that variations in upwelling driven by variations in the strength of the monsoon are responsible for the observed variations in the sediment record.

There are obvious limitations to this modelling approach. The most fundamental is in the coarse spatial and temporal resolution of the model winds used to drive the ocean simulations. The wind stress curl depends crucially on the width of the Findlater Jet, which in turn depends how well the Jet is resolved. Other studies have suggested that the abrupt onset of the southwest monsoon winds is important in the development of the oceanic response. This abrupt onset is not captured by a single annual harmonic as is used in the present approach. The preferred approach is to use monthly averaged winds as are used by Luther and O'Brien [1985] and'subsequent studies. Still, the generally good agreement between the control-case and previous simulations using modem climatological monthly mean winds suggests that these are not serious deficiencies. The ocean model does not explicitly simulate upwelling, since no mass is exchanged between the surface layer and the deep layer of the model ocean. Rather, upwelling is inferred from upward motions of the model pycnocline. Additionally, the model does not include the effects of thermodynamic processes such as turbulent entrainment, which are shown to be important in some aspects of the Arabian Sea circulation by $M c C$ reary and Kundu $[1988,1989]$. For the purposes of the present study, however, the model is quite sufficient. The gross aspects of the upwelling variability on interglacial time scales are adequately represented.

Acknowledgments. The authors thank John Kutzbach and Peter Guetter for generously providing the wind fields used in this study and for many helpful discussions. This work was supported in part by the Office of Naval Research, by the National Oceanic and Atmospheric Administration, by the Department of Energy, and by the Naval Ocean and Atmospheric Research Laboratory. Additional support was provided by the Florida State University through time granted on its Cyber 205 and ETA 10 supercomputers. This is a contribution of the Geophysical Fluid Dynamics Institute and of the Supercomputer Computations Research Institute at the Florida State University. The Supercomputer Computations Research Institute is funded by the Department of Energy.

\section{REFERENCES}

Cadet, D. L., and B. C. Diehl, Interannual variability of surface fields over the Indian Ocean during recent decades, Mon. Weather Rev., 112, 1921-1935, 1984.

Cullen, J. L., and W. L. Prell, Planktonic foraminifers in northern Indian Ocean surface sediments: Distribution and preservation, Mar. Micropaleontol., 9, pp. 1-52, 1984.

Findlater, J., Mean monthly airflow at low levels over the westem Indian Ocean, Geophys. Mem., 115, 53 pp, 1971.

Hastenrath, S., Climate and Circulation of the Tropics, 455 pp., D. Reidel, Higham, Mass., 1985.

Hutson, W. H., and W. L. and Prell, A paleontologic transfer function, FI-2, for Indian Ocean planktonic foraminifera, $J$. Paleoniol., 54, 381-399, 1980.

Kindle, J, C. and J. D. Thompson, The 26- and 50-day oscillations in the western Indian Ocean: Model results, $J$. Geophys. Res., 94, 4721-4736, 1989.

Knox, R. A., The Indian Ocean: Interaction with the monsoons, Monsoons, edited by J. Fein and P. Stephens, pp. 365-398, John Wiley, New York, 1987.

Kutzbach, J. E., Monsoon climate of the early Holocene; climatic experiment using earth's orbital parameters from 9,000 years ago, Science, 214, 59-61, 1981.

Kutzbach, J. E., The changing pulse of the monsoon, Monsoons, edited by J. Fein and P. Stephens, pp. 247268, John Wiley, New York, 1987.

Kutzbach, J. E., and P. J. Guetter, The influence of changing orbital parameters and surface boundary conditions on climate simulations for the past 18,000 years, $J$. Atmos. Sci., 43, 1726-1759, 1986.

Kutzbach, J. E. and B. L. Otto-Bliesner, The sensitivity of the African-Asian monsoon to orbital parameter changes for 9,000 B.P. in a low-resolution general circulation model, $J$. Atmaos. Sci., 39, 1177-1188, 1982.

Luther, M. E., and J. J. O'Brien, A model of the seasonal circulation in the Arabian Sea forced by observed winds, Prog. Oceanogr., 14, 353-385, 1985.

Luther, M. E., and J. J. O'Brien, Modelling the variability in the Somali Current, in Mesoscale/Synoptic Coherent Structures in Geophysical Turbulence, edited by J. C. J. Nihoul and B. M. Jamart, pp. 373-386,, Elsevier Science, New York, 1989.

Luther, M. E., J. J. O'Brien, and A. H. Meng, Morphology of the Somali Current system during the southwest monsoon, in Coupled Ocean-Atmosphere Models, edited by J. C. J. Nihoul, pp. 405-437, Elsevier Science, New York, 1985.

McCreary, J. P. , and P. Kundu, A numerical investigation of the Somali Current during the southwest monsoon, J. Mar. Res., 46, 25-58, 1988.

McCreary, J. P., and P. K. Kundu, A numerical investigation of sea surface temperature variability in the Arabian Sea, $J$. Geophys. Res., 94, 16,097-16,114, 1989.

Moore, D. W., and J. P. McCreary, Excitation of intermediatefrequency equatorial waves at a western ocean boundary: With application to observations from the Indian Ocean, $J$. Geophys. Res., 95, 5219-5231, 1989.

O'Brien, J. J., and H. E. Hurlburt, Equatorial jet in the Indian Ocean: Theory, Science, 184, 1075-1077, 1974.

Prell, W. L., Variation of monsoon upwelling: A response to 
changing solar radiation, in Climate Processes and Sensitivity, Geophys. Monogr. Ser., vol. 29, edited by J. E. Hansen and T. Takahshi, pp. 48-57, AGU, Washington, D. C., 1984a.

Prell, W. L., Monsoonal climate of the Arabian Sea during the Late Quaternary: A response to changing solar radiation, Milankovitch and Climate, edited by A. Berger, J. Imbrie, J. Hays, G. Kukla, and B. Saltzman, eds., pp. 349-366, D. Reidel, Hingham, Mass., 1984b.

Prell, W. L., and W. B. Curry, Faunal and isotopic indices of the southwest monsoon upwelling, Arabian Sea, Oceanol. Acta, 4, 91-98, 1981.

Prell, W. L., and J. E. Kutzbach, Monsoon variability over the past 150,000 years, J. Geophys. Res., 92, 8411-8425, 1987.

Prell, W. L., and E. van Campo, Coherent response of Arabian Sea upwelling and pollen transport to Late Quaternary monsoonal winds, Nature, 323, 526-528, 1986.

Prell, W. L., W. H. Hutson, D. F. Williams, A. W. H. Be, R. Geitzenauer, and B. Molfino, Surface Circulation of the Indian Ocean during the last interglacial maximum, approximately 18,000 yr B.P., Quar. Res. N. Y., 14, 309336, 1980

Prell, W. L., R. E. Marvil and M. E. Luther, Variability in upwelling fields in the northwestem Indian Ocean, 2, Datamodel comparison at 9000 years B.P., Paleoceanogr., this issue.

Simmons, R. C., M. E. Luther, J. J. O'Brien, and D. M. Legler, Verification of a numerical ocean model of the Arabian Sea, J. Geophys. Res., 93, 15,437-15,453, 1988.

Schott, F., Monsoon response of the Somali Current and associated upwelling, Prog. Oceanogr., 12, 357-382, 1983.

Smith, R. L., and J. S. Bottero, On upwelling in the Arabian Sea, in $A$ Voyage of Discovery, edited by M. Angel, pp. 291-304, Pergamon, New York, 1977.
Street-Perrot, F. A., and S. P. Harrison, Temporal variations in lake levels since 30,000 yr B.P. - an index of the global hydrological cycle, in Climate Processes and Climate Sensitivity, Geophys. Monogr. Ser., vol. 29, edited by J. E. Hansen and T. Takahashi, pp. 118-129, AGU, Washington, D.C., 1984.

Swallow, J. C., R. L. Molinari, J. G. Bruce, O. B. Brown, and $R$. H. Evans, Development of near-surface flow patterns and water mass distribution in the Somali Basin in response to the southwest monsoon of 1979, J. Phys. Oceanogr., 13, 1398-1415, 1983.

van Campo, E., Paleoclimatologie des bordures de la mer d'arabie depuis 150,000 ans. analyse pollinique et stratigraphie isotopique, Ph.D. thesis, 114 pp., Acad. de Montpellier, France, 1983.

van Campo, E., J. C. Duplessy, and M. Rossignol-Strick, Climatic conditions from a 150-kyr oxygen isotope-pollen record from the Arabian Sea, Nature, 296, 56-59, 1982

Woodberry, K. E., M. E. Luther, and J. J. O'Brien, The wind driven seasonal circulation in the southern tropical Indian Ocean, J. Geophys. Res., 94, 17,985-18002, 1989.

Wyrtki, K., An equatorial jet in the Indian Ocean, Science, $181,262-264,1973$.

M. E. Luther, Department of Marine Science, University of South Florida St. Petersburg, 140 Seventh Avenue South, St. Petersburg, FL 33701-5016.

J. J. O'Brien, Mesoscale Air-Sea Interaction Group, B-174, Florida State University, Tallahassee, FL 32306-3041. W. L. Prell, Department of Geological Sciences, Brown University, Providence, RI 02912.

(Received September 1, 1989; accepted January 26, 1990.) 